\title{
Vegetation classification as the basis for baboon management in the Bourke's Luck Section of the Blyde Canyon Nature Reserve, Mpumalanga
}

\author{
L.R. Brown, H. Marais, S.P. Henzi and L. BarRetT
}

Brown, L.R., H. Marais, S.P. Henzi and L. Barrett. 2005. Vegetation classification as the basis for baboon management in the Bourke's Luck Section of the Blyde Canyon Nature Reserve, Mpumalanga. Koedoe 48(2): 71-92. Pretoria. ISSN 0075-6458.

The Blyde Canyon Nature Reserve (BCNR) was identified as an important conservation area due to of its extraordinary diversity of plant species. Plant communities represent ecosystems and form the basis of any management plan for natural areas. If these ecosystems and their different potentials are unknown, they cannot be managed successfully. Baboons exploit diverse habitats including human environments where they often cause damage to crops and forest plantations. Baboons are regarded as particularly problematic residents of protected areas as conventional fences do not readily enclose them, their eclectic diets allow them to benefit from a range of agricultural endeavours, and they are behaviourally opportunistic. Thus as a first step to implementing a conservation policy to manage chacma baboons in the BCNR, it was necessary to have some understanding of their exploitation of natural habitats adjacent to areas where they do cause problems. Although a broad vegetation map of the BCNR exists, no detailed vegetation studies have been conducted on the largest part of the reserve. It was therefore decided to undertake a detailed vegetation study of the home range of a single baboon troop within the Bourke's Luck section of the BCNR. From a TWINSPAN classification, refined by Braun-Blanquet procedures, 13 plant communities, which can be grouped into seven major groups, were identified. A classification and description of these communities, as well as a vegetation map are presented. Data collected as part of this study also revealed that the baboons show preference to certain communities whilst avoiding others. These have important consequences in terms of the management strategies followed on the reserve.

Keywords: Braun-Blanquet procedures, conservation area, plant communities, TWINSPAN, TURBOVEG, MEGATAB, chacma baboons.

L.R. Brown $₫$, H. Marais, Applied Behavioural Ecology \& Ecosystem Research Unit, University of South Africa, Private Bag X6, Florida, 1710 Republic of South Africa; S.P. Henzi, Behavioural Ecology Research Group, University of KwaZulu-Natal (Present address: Department of Psychology, University of Central Lancashire, UK); L. Barrett, School of Biological Science, University of Liverpool, UK.

\section{Introduction}

The Mpumalanga Province of South Africa has an extraordinary diversity of plant species with an estimated 4946 plant taxa occurring within the province (Lotter et al. 2002). The importance of the escarpment area is emphasised through its identification as an important centre for endemism (Fourie et al. 1988; Matthews et al. 1993). The Blyde Canyon Nature Reserve (BCNR) in particular was identified as an important conserva- tion area in this respect (Bredenkamp et al. 1996).

Nature reserves provide reservoirs of a country's fauna and flora (Greyling \& Huntley 1984). It is therefore important to investigate their natural resources to compile scientifically sound management programmes and conservation policies (Brown et al. 1996; Brown 1997). Ecosystems react differently to different management practices (Bredenkamp 1982; Bezuidenhout 1993), there- 
fore it is important that a description and classification of the vegetation of an area is done (Van Rooyen et al. 1981). It is widely recognised that a detailed description, identification, classification and mapping of the vegetation form the basis for sound land-use planning and management (Tueller 1988; Fulls et al. 1992; Fulls 1993; Bezuidenhout 1996; Brown et al. 1997). Ecological inventories of the vegetation in conservation areas as the habitat for plants and animals therefore have a central position in nature conservation (Bredenkamp \& Brown 2001; Brown et al. 1996).

Plant communities represent ecosystems and form the basis of any management plan for natural areas. If these ecosystems and their different potentials are unknown, they cannot be managed successfully (Brown \& Brand 2004). Various animal species occupy and utilise different plant communities for different activities such as sleeping, feeding and reproducing. The study of the vegetation (plant communities) of the home range of any animal must therefore form the basis when investigating its ecology, social interaction and dietary requirements (Brown 2003).

Baboons, as highly intelligent and ecologically flexible animals, exploit diverse habitats. They forage on a wide variety of plant species, insects, reptiles and often mammals. Although baboons are mainly vegetarian, the main feature of their diet is the ability to adapt to any environment and to utilise whatever food is available (De Vore \& Hall 1965). Part of this flexibility has the consequence that they exploit human habitats, often causing damage to crops and forest plantations as well as to human dwellings. This has led to baboons being regarded as problem animals that should be eradicated from these areas.

At present, nature conservation authorities have limited management plans or guidelines with regard to baboons. Thus, as a first step to implementing a conservation policy to manage baboons in the BCNR, it was deemed necessary to have some understand- ing of their exploitation of natural habitats next to areas where they do cause problems. No policies regarding nature conservation can be developed if it is unknown what is to be conserved, why it has to be conserved or what the present status is (Anon. 1985).

The BCNR is a large, protected area surrounded by both subsistence and commercial agricultural ventures of which commercial pine tree plantations dominate. Although baboons are known to cause damage to young pine trees at a commercially significant rate (Bigalke \& van Hensbergen 1990), this damage is not severe at the BCNR. Since it is possible that utilisation of pine plantations is driven by the local destruction of natural habitat, it is important to determine the extent to, and conditions under which baboons damage pine trees where they have the full range of natural vegetation available to them.

As part of a study to determine and quantify the habitat use of baboons, it was essential to undertake a detailed vegetation study of the home range of a single baboon troop within the Bourke's Luck section of the BCNR. Since 1985, various vegetation studies were conducted on the broader vegetation types of the north eastern mountain region of Mpumalanga (Deall 1985; Deall et al. 1989a, 1989b; Matthews et al. 1991). Although a broad vegetation map of the BCNR exists, no detailed vegetation studies have been conducted on the largest part of the reserve. The main aim of this study was therefore to describe and map the plant communities of the Bourke's Luck section of the reserve.

\section{Study area}

The BCNR extends across 26818 ha and is situated on the northern and western boundaries of the town of Graskop (Fig. 1). The BCNR is located along the Great Escarpment in the Mpumalanga Province of South Africa at latitude $24^{\circ} 27^{\prime}-25^{\circ} 56^{\prime} \mathrm{S}$ and longitude $30^{\circ} 44^{\prime}-30^{\circ} 55^{\prime} \mathrm{E}$. 


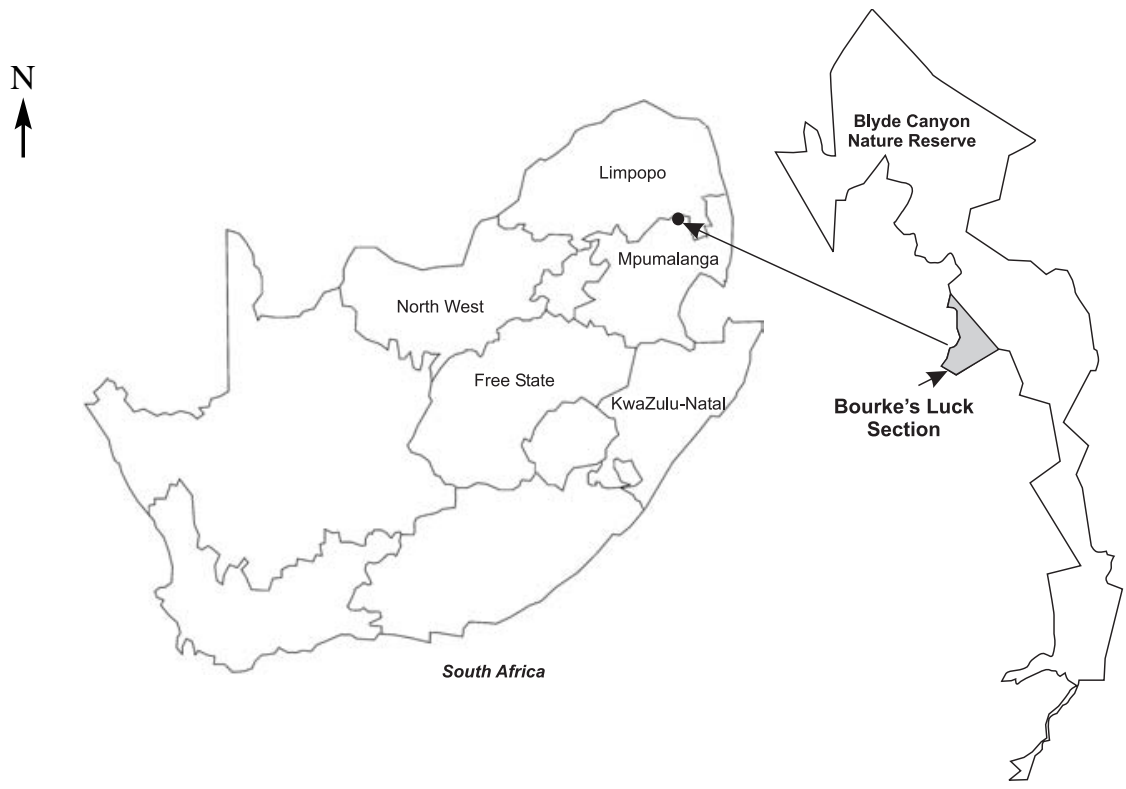

Fig. 1. A map of South Africa showing the location of the Blyde Canyon Nature Reserve (BCNR), including the Bourke's Luck section, the focus of this study.

The study area (Bourke's Luck section) is 524.4 ha in size and receives an average of $857 \mathrm{~mm}$ of rain annually. The average annual rainfall for the last 10 years was $700 \mathrm{~mm}-$ $1400 \mathrm{~mm}$ (Fig. 2). Average daily temperatures range from $11.5^{\circ} \mathrm{C}$ to $21.3^{\circ} \mathrm{C}$ (Fig. 2). Temperatures descend to below $0{ }^{\circ} \mathrm{C}$ in winter and rise above $30{ }^{\circ} \mathrm{C}$ in summer.

Two land types, namely Fa and Ic occur in the Bourke's Luck section of the Blyde Canyon Nature Reserve as indicated in the terrain form sketch (Fig. 3). The land type unit Fa refers to red apedal, medium sandy loam, well drained, soil which is shallower than $1000 \mathrm{~mm}$. The overall terrain type is relatively flat with more than $60 \%$ of the surface having a slope of less than $5 \%$. The predominant geology of this land type is quartzite, conglomerate, shale and basalt of the Black Reef Formation, Transvaal Sequence. The foot slopes are rocky with an average rock cover of $19 \%$, while the dominant soil type, Hutton, is found on the crest

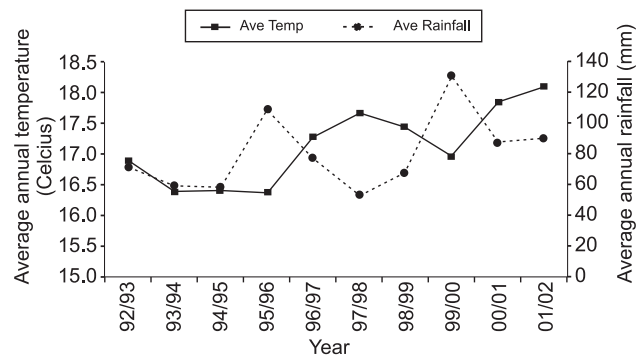

Fig. 2. The average annual rainfall and temperature of the Bourke's Luck section on the BCNR for ten years (1992-2002).

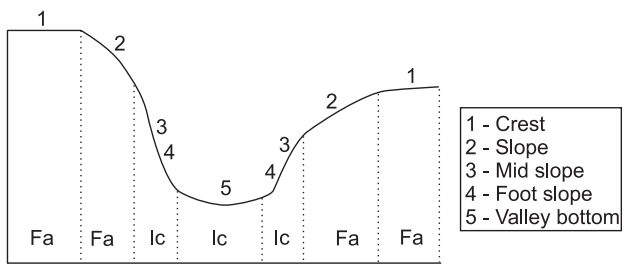

Fig. 3. A terrain form sketch indicating the different land types of the study area 
of the terrain unit (Land Type Survey Staff 1989).

The Ic land type refers to land types with exposed rocks covering $60-80 \%$ of the area. The soil varies from dark brown orthic soils to loamy fine sand and is very shallow $(<100 \mathrm{~mm})$. The dominant soil type is Mispah, present on the midslopes. The geology consists of shale, quartzite, conglomerate and basalt of the Wolkberg Group, Transvaal Sequence (Land Type Survey Staff 1989).

\section{Methods}

In order to distribute sample plots efficiently and effectively so that all relevant variation in vegetation would be sampled, the research area was stratified into physiognomic-physiographic units by using 1:20 000 stereo aerial photographs. These units were then verified in the field and the necessary changes effected to ensure that all variations in the vegetation were considered and sampled. A total of 61 relevés were located in a stratified random manner within these units. Plot sizes were fixed at approximately $200 \mathrm{~m}^{2}$ in accordance with Bredenkamp (1982).

The cover-abundance of each species was assessed according to the Braun-Blanquet cover-abundance scale (Mueller-Dombois \& Ellenberg 1974). Plant taxon names conform to those of Germishuizen \& Meyer (2003). The percentage cover of grasses and herbaceous plants, shrubs (woody species varying in height between $>0-3 \mathrm{~m}$ ) and trees (woody species $>3 \mathrm{~m}$ in height) were also estimated. The locality of each plot was determined using a Global Positioning System. Environmental data recorded included geology, soil texture, degree of erosion, a measurement of aspect using a compass, and slope with the aid of a clinometer.

All relevé data has been imported into the database TURBOVEG (Hennekens 1996a). The numerical classification program TWINSPAN (Hill 1979), which is regarded as a successful approach for classification by several phytosociologists (Mucina \& Van der Maarel 1989; Bredenkamp \& Bezuidenhout 1995; Cilliers 1998) was used to derive a first approximation of the floristic data. Subsequently Braun-Blanquet procedures (Bezuidenhout et al. 1996) were used to refine data and construct a phytosociological table (Table 1) using a visual editor, MEGATAB (Hennekens 1996b). Uncommon species not diagnostic for any of the communities are not included in the table, but are available upon request to the corresponding author. Using the phytosociological table and the habitat information gathered during the sampling period, the different plant communities was identified and described. Plant communities were recognised by using diagnostic species as defined by Westhoff \& Van der Maarel (1978). Diagnostic/character species are those that are relatively restricted to a community. These species do not necessarily have a high importance value. The different plant communities are described according to their dominant species. Dominant species are those that are most conspicuous in the community and are high in one or more of the importance values (Whittaker 1978), in this case cover and frequency. No attempt was made to formally fix syntaxa names formally as this is normally avoided in detailed local studies (Coetzee 1983).

\section{Results}

\section{Classification}

Approximately two thirds of the study area comprises grassland vegetation found predominantly on high and low altitudes while the rest consist of woodland vegetation. The grasses Loudetia simplex and Sporobolus pectinatus together with the dwarf shrubs Helichrysum kraussii, Pearsonia sessilifolia and Fadogia tetraquetra (species groups $\mathrm{M}$ and N, Table 1) are prominent throughout the grassland vegetation and will not necessarily be mentioned repeatedly in the descriptions of the different plant communities.

Due to the complex and heterogeneous topography and consequent climate differences in the study area a great variation exists in the habitat which has resulted in the recognition of 13 plant communities, which can be grouped into seven major community types (Fig. 4 \& Table 1). The hierarchical classification of the vegetation indicates a strong association between the different plant communities and their respective habitats. The following plant communities were recognised in the study area and are described (all species groups are indicated in Table 1 and no specific reference will therefore be made to the table in the description of the different plant communities):

1. Hyperthelia dissoluta-Heteropogon contortus Grassland

2 Diheteropogon amplectens-Loudetia simplex Grassland 
2.1 Diheteropogon amplectens-

Monocymbium ceresiiforme Grassland

2.1.1 Hemizygia transvaalensisThemeda triandra Grassland

2.1.2 Diheteropogon amplectensPearsonia sessilifolia Shrubland

2.2 Helichrysum wilmsii-Panicum natalense Grassland

2.3 Diheteropogon amplectens-Brachiaria serrata Grassland

2.3.1 Eragrostis gummiflua-Loudetia simplex Grassland

2.3.2 Fadogia tetraquetra-Euclea linearis Shrubland

2.4 Senecio glaberrimus-Pearsonia sessilifolia Shrubland

3. Englerophytum magalismontanum-Helichrysum kraussii Shrubland

4. Pterocarpus angolensis-Englerophytum magalismontanum Woodland

5. Faurea saligna-Cymbopogon vallidus Woodland

6. Combretum kraussii-Acacia ataxacantha Woodland

6.1 Englerophytum magalismontanumAcacia ataxacantha Woodland

6.2 Combretum kraussii- Acacia ataxacantha Woodland

7. Pinus patula Woodland

\section{Description of the plant communities}

1. Hyperthelia dissoluta-Heteropogon contortus Grassland

The Hyperthelia dissoluta-Heteropogon contortus Grassland is situated in the southern section of the study area and is elevated above the Treur River (Fig. 4). The terrain is relatively flat with an eastern slope of $5-6^{\circ}$ and an altitude of $1180 \mathrm{~m}$ above sea level. No visible rocks are present and although the soil is deeper than that of other communities in the study area, it is still fairly shallow.

The diagnostic species include the grasses Heteropogon contortus and Hyperthelia dissoluta together with the forbs Verbena brasiliensis and Helichrysum callicomum (species group A).

There is no tree or shrub layer present and the vegetation is characterised by the presence of a herbaceous layer only. The grass layer has an $80 \%$ coverage, while the forb layer covers $10 \%$ of the area. The grasses Heteropogon contortus (species group A) and Hyperthelia dissoluta (species group A) dominate this community, while Hyparrhenia filipendula (species group D) and Diheteropogon amplectens (species group B) are also prominent within this community. The grass Themeda triandra (species group C) is prominent locally. Prominent forbs include Helichrysum nudifolium, Senecio junodii (species group D) and Crotalaria doidgeae (species group $\mathrm{M}$ ).

This community comprises 14.3 ha which is $2.7 \%$ of the total study area. An average of 13 species $/ 200 \mathrm{~m}^{2}$ was recorded in this plant community. This community is on average burnt every year which explains the low species richness, as well as the presence of the grasses Heteropogon contortus (species group A), Hyperthelia dissoluta (species group A), Hyparrhenia filipendula (species group D), Diheteropogon amplectens (species group B) and Themeda triandra (species group C) all of which are fire climax grasses that are stimulated by a regular fire regime.

The disturbed nature of this community is also reflected in the presence of the pioneer grass Melinis repens (species group V) and the pioneer forb Verbena brasiliensis (species group A).

2. Diheteropogon amplectens-Loudetia simplex Grassland

This grassland community is found throughout the study area on high-lying areas and mid slopes. The terrain is generally flat with gentle slopes. Altitude ranges from $1140 \mathrm{~m}-1280 \mathrm{~m}$ asl. The area has distinctive flat rocky sections with rockiness varying between 5-70\%. Soil depth varies from shallow to very shallow.

Species diagnostic for this community are the grasses Diheteropogon amplectens, Aristida junciformis, the dwarf shrub Lannea edulis, the forbs Hemizygia transvaalensis, Phymaspermum acerosum, Senecio scitus, Bulbostylis burchellii, and Vernonia natalensis (species group $\mathrm{B}$ ).

The woody layer is absent and this community comprises a grass layer with a 15-70\% 


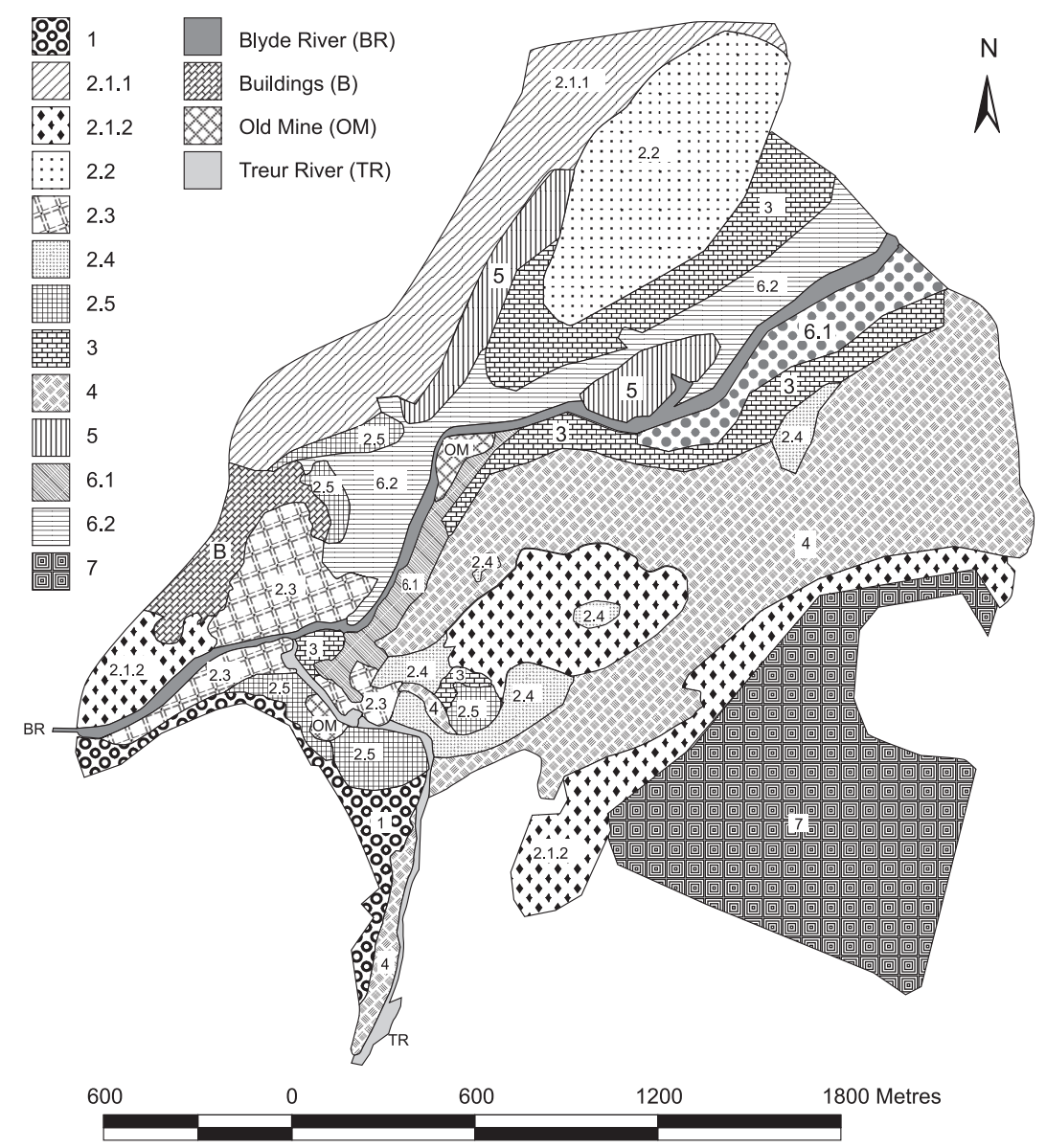

Fig. 4. Distribution of the different vegetation types on the Bourke's Luck section of the Blyde Canyon Nature Reserve.

cover. The vegetation is dominated by the grasses Loudetia simplex (species group $\mathrm{M}$ ) Diheteropogon amplectens (species group B) and Sporobolus pectinatus (species group M). The forbs Bulbostylis burchellii, Hemizigya transvaalensis (species group B), Helichrysum kraussii and Crotalaria doidgeae (species group $\mathrm{M}$ ) are also prominent. The endemic forb Hemizygia parvifolia (species group $\mathrm{O}$ ) is locally present in this community.
This major community shows affinity to the Hemizygio-Loudetia simplex association as described by Matthews et al. (1991) and the Diheteropogon plectentis-Proteetum gaguedi sub-association as described by Matthews et al. (1994). Sections (sub-communities 2.1, 2.2) of the Diheteropogon amplectensLoudetia simplex grassland are characteristic of the drier and higher altitude communities as described by Matthews et al. (1991) and Matthews et al. (1994). 


\subsection{Diheteropogon amplectens-Monocymbium ceresiiforme Grassland}

The Diheteropogon amplectens-Monocymbium ceresiiforme Grassland consists of high altitude grassland ranging between $1140 \mathrm{~m}-$ $1280 \mathrm{~m}$ asl. The area is generally flat with a slope of $2-6^{\circ}$ southwest with shallow soils. Rocky cover varies between 5-60\%.

This sub-community is characterised by the species belonging to species group $\mathrm{E}$ and includes the grasses Monocymbium ceresiiforme, Eragrostis capensis and the forbs Athrixia phyllicoides, Triumfetta welwitchia, Helichrysum cooperi and Lotononis eriantha.

The tree layer has a $0-5 \%$ cover, the grass layer $15-50 \%$ cover, and the forb layer a 30$55 \%$ cover. The grasses Diheteropogon amplectens (species group B) and Monocymbium ceresiiforme (species group E) together with the aromatic forb Hemizygia transvaalensis (species group B) dominate this community, while the grasses Loudetia simplex and Sporobolus pectinatus (species group M) are locally prominent. The grasses Aristida junciformis (species group B) and Eragrostis racemosa (species group $\mathrm{H}$ ) are also characteristic of this sub-community. Prominent forbs include Acalypha villicaulis (species group M), Bulbostylis burchellii and Phymaspermum acerosum (species group B).

This sub-community covers and area of 119.3 ha which is $22.8 \%$ of the total study area. Due to accidental burns the fire frequency varies between one to two years. An average of 35 species/200 $\mathrm{m}^{2}$ was recorded within this community.

The prominence and presence of the grasses Aristida junciformis (species group B), Themeda triandra, Bewsia biflora (species group (C), Monocymbium ceresiiforme (species group E), Panicum natalense (species group F), Eragrostis racemosa (species group H), Loudetia simplex (species group M) and the forb Bulbostylis burchellii (species group B) within this sub-community shows a remarkable similarity to the Monocymbium ceresiiforme-Loudetia simplex grassland found on the Bankenveld
(Bredenkamp \& Brown 2003). The presence of the species Monocymbium ceresiiforme (species group E), Loudetia simplex (species group M), Panicum natalense (species group F), Themeda triandra (species group C) and Cyanotis speciosa (species group O) also indicates an affinity to the Drakensberg vegetation.

\subsubsection{Hemizygia transvaalensis-Themeda triandra Grassland}

This variant is predominantly found in grasslands with a gentle $\left(6^{\circ}\right)$ south-western slope and is situated in the north-western border of the study area (Fig. 4). Altitude varies between 1160-1200 $\mathrm{m}$ asl. The soil is shallow and shows signs of early disturbance from mining and old road works. The estimated rockiness is $5 \%$.

The following species belonging to species group $\mathrm{C}$, are diagnostic for this variant: Setaria ustilata, Bewsia biflora, Eragrostis curvula, Themeda triandra and the forbs Agathisanthemum bojeri, Nidorella auriculata, Crassula lanceolata, Helichrysum oxyphyllum and Tephrosia lupinifolia.

The woody layer consists of the dwarf shrub Lannea edulis (species group B) that occurs scattered in small clumps throughout the area covering an estimated $1-5 \%$ of the area. The herbaceous layer is the most prominent with the grasses covering an estimated $45 \%$ of the area and the forb layer covering between $25-55 \%$ of the area.

The vegetation is dominated by the grasses Themeda triandra (species group C), Diheteropogon amplectens (species group B), Monocymbium ceresiiforme (species group E) and the aromatic forb Hemizygia transvaalensis (species group $\mathrm{B}$ ). Other grasses that are also present include Aristida junciformis (species group B) and Sporobolus pectinatus (species group $\mathrm{M}$ ). Prominent forbs include Commelina africana (species group M) and Helichrysum cooperi (species group E) while Helichrysum nudifolium (species group D), Pearsonia sessilifolia filifolia (species group $\mathrm{H}$ ) and Crotalaria 


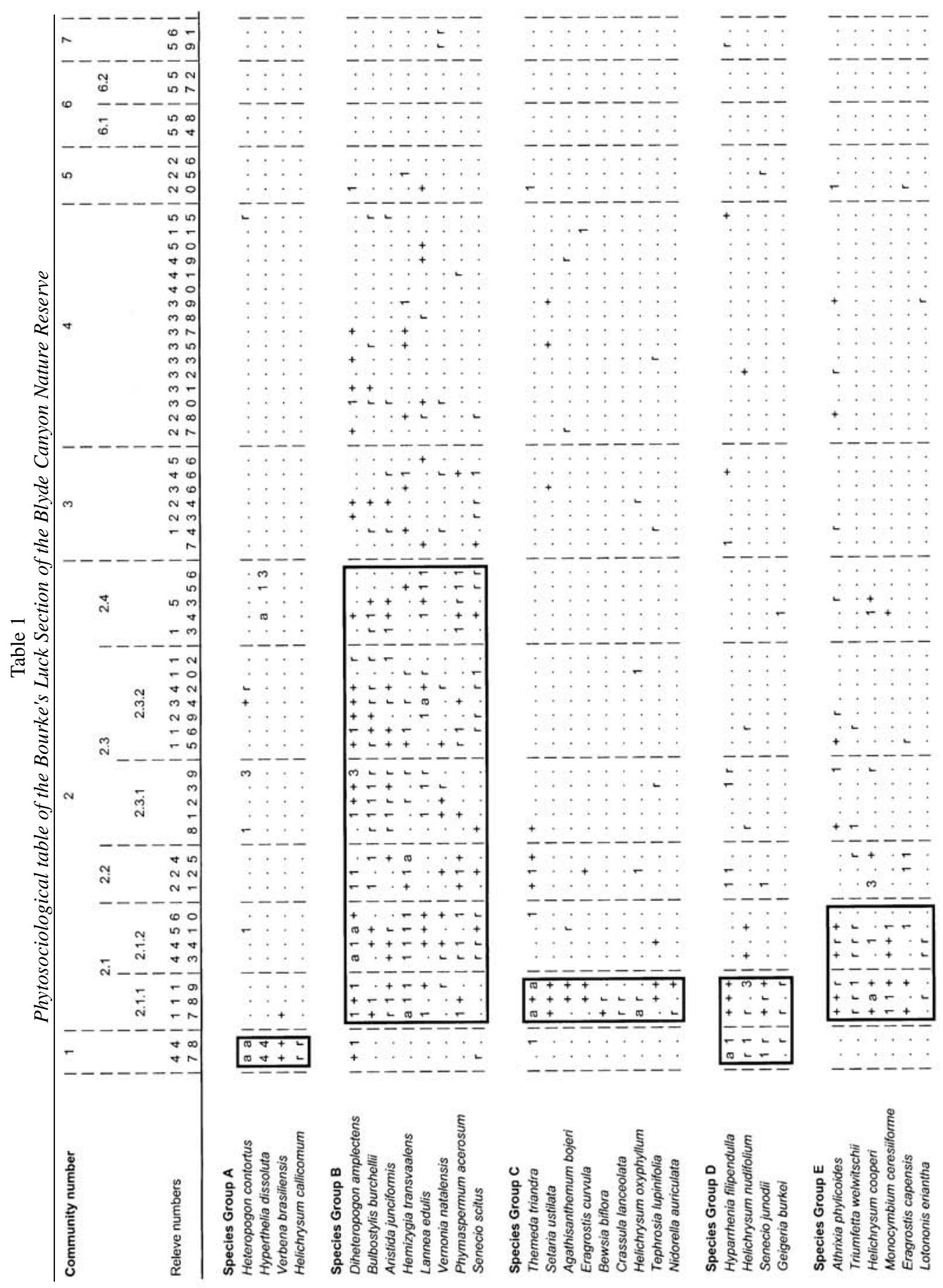




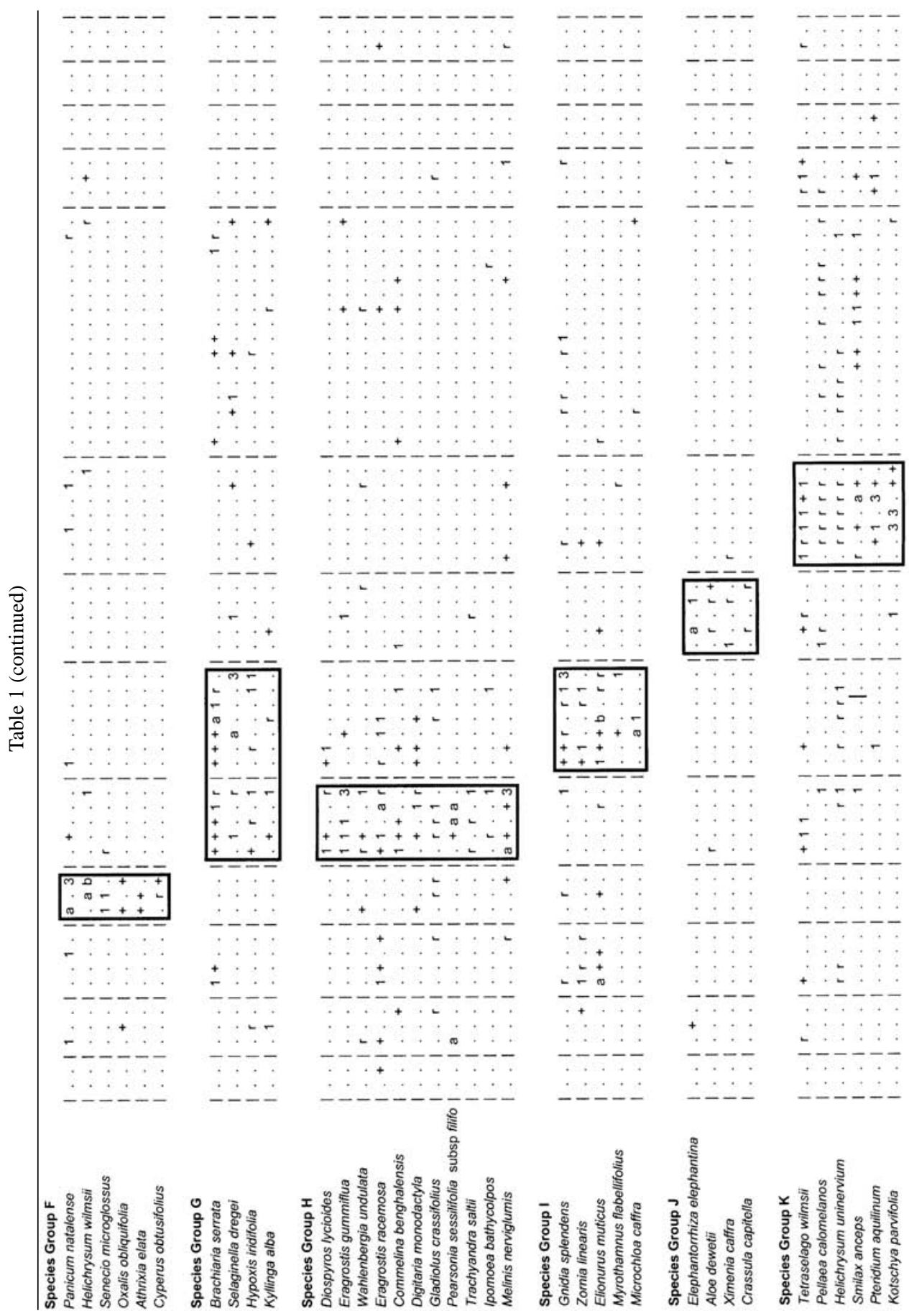




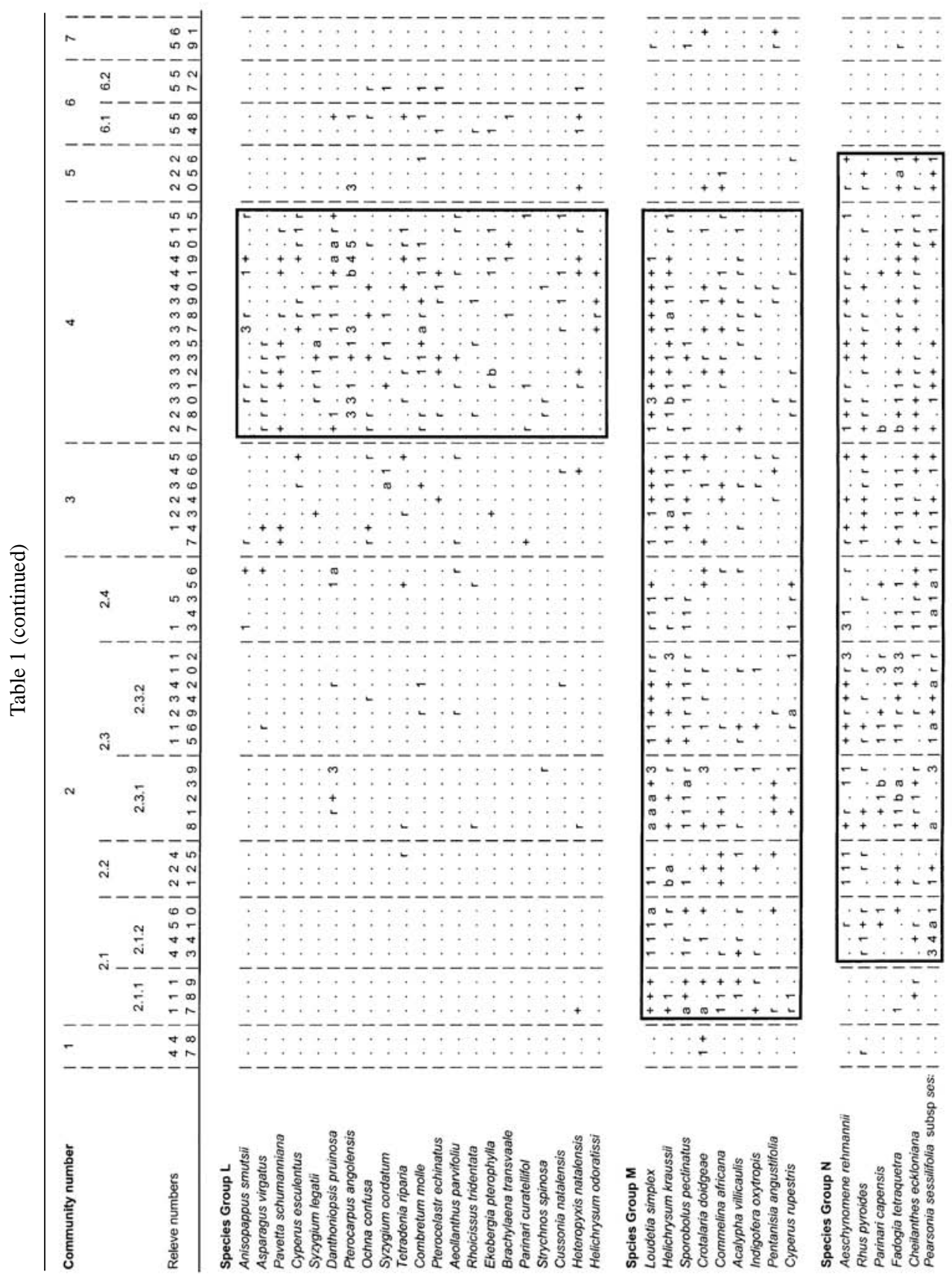




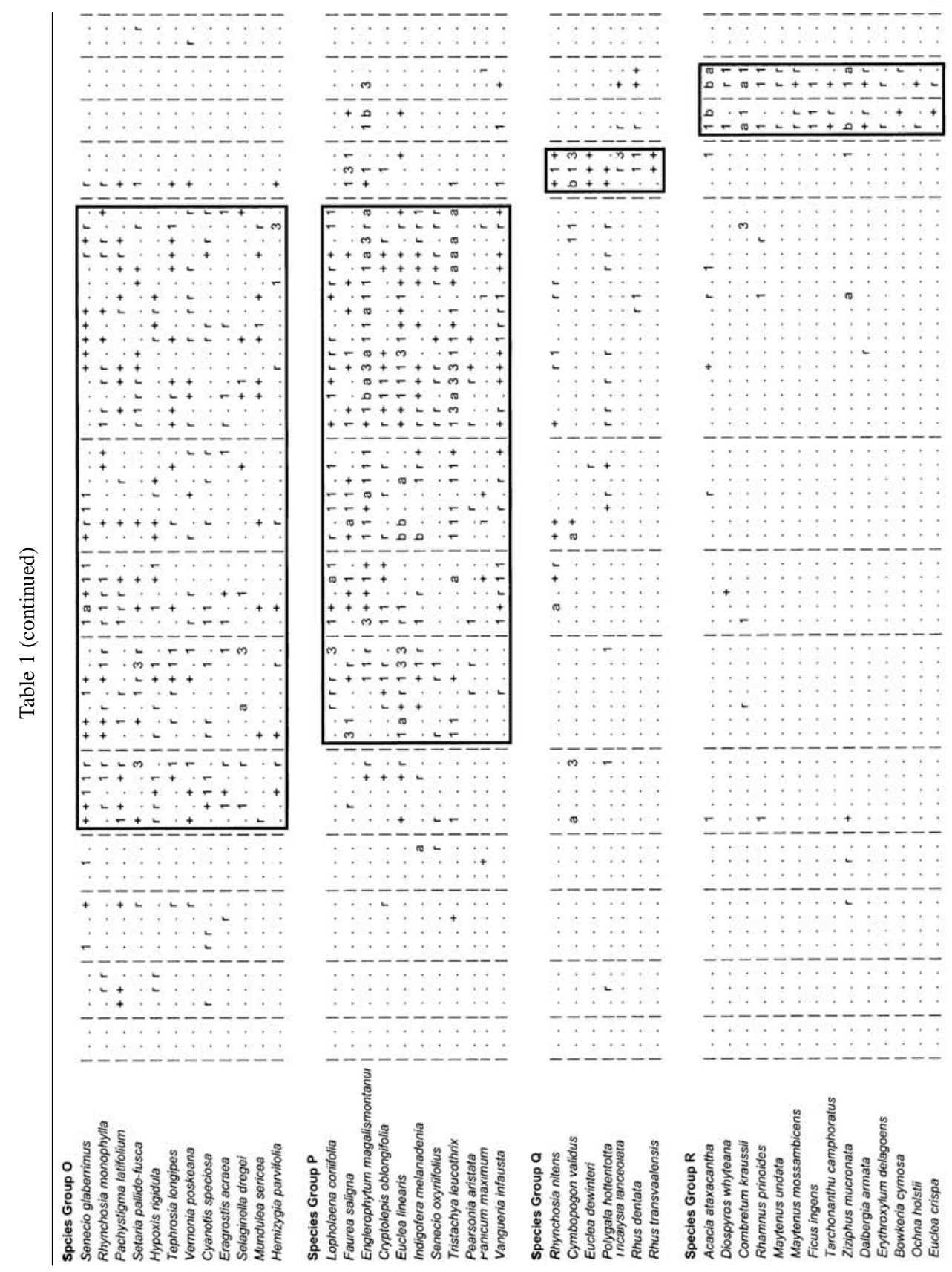




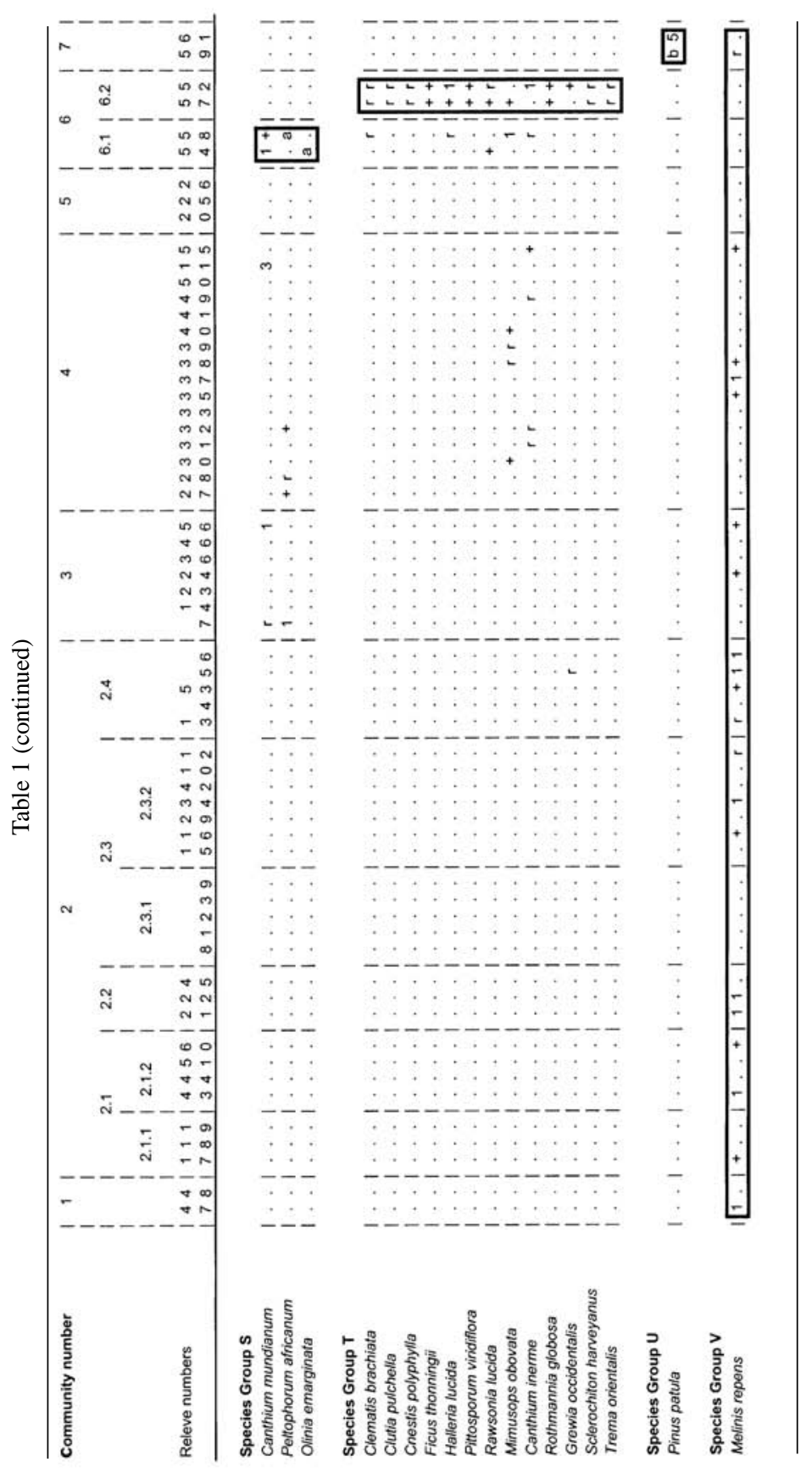


doidgeae (species group $\mathrm{M}$ ) are also present in this variant.

\subsubsection{Diheteropogon amplectens- Pearsonia sessilifolia Shrubland}

This variant occurs in higher lying grassland in the central and eastern section of the study area (Fig. 4) with gentle slopes ranging between $2-6^{\circ}$ south. Altitude ranges between $1140-1280 \mathrm{~m}$ above sea level. The soil is shallow while rockiness varies between 30-60\%.

This variant is characterised by the absence of species belonging to species group $\mathrm{D}$.

The woody layer comprises scattered trees and shrubs with a $0-5 \%$ and $5-15 \%$ coverage respectively. The grass layer has a $15-50 \%$ cover and the forbs $30-50 \%$ coverage.

The vegetation is dominated by grass Diheteropogon amplectens (species group B) and the distinctive silvery forb Pearsonia sessilifolia subsp. sessilifolia (species group $\mathrm{N}$ ). The grass Loudetia simplex (species group M) and the aromatic forb Hemizygia transvaalensis (species group B) are very prominent as well. Other species present include the dwarf shrub Lannea edulis (species group B), the grasses Eragrostis racemosa (species group $\mathrm{H}$ ), Elionurus muticus (species group I), Brachiaria serrata (species group G) and Sporobolus pectinatus (species group M), and the forbs Phymaspermum acerosum (species group B), Zornia linearis (species group I) and Crotalaria doidgeae (species group M).

\subsection{Helichrysum wilmsii-Panicum natalense Grassland}

This sub-community occurs on the higher, more flat grassland area in the northern section of the study area (Fig. 4). The altitude varies between 1260-1280 $\mathrm{m}$ above sea level, with a $5^{\circ}$ south-western slope. The soil is shallow with a low rock cover ranging between $5-15 \%$.
There are no trees present and dwarf shrubs with an estimated $5 \%$ cover represent the woody layer. The grasses with 35-70\% cover and the forbs with $30-50 \%$ cover are the most prominent vegetation layers.

Diagnostic species of this sub-community include: Panicum natalense, Helichrysum wilmsii, Senecio macroglossus, Oxalis obliquifolia, Athrixia alata, and Cyperus obtusifloris (species group F).

Dominant species of this sub-community include the grasses Panicum natalense (species group F), Loudetia simplex (species group M) and the shrub Helichrysum wilmsii (species group F). Prominent species are the forbs Aeschynomene rehmannii (species group N), Helichrysum kraussii (species group $\mathrm{M}$ ) and Hemizygia transvaalensis (species group B). The forbs Helichrysum cooperi (species group E), Commelina africana (species group M), Phymaspermum acerosum (species group B) and the grass Themeda triandra (species group C) are also present in this sub community.

With a size of 47.8 ha, this community represents $9 \%$ of the total study area. The average number of species recorded within this plant community is $27 / 200 \mathrm{~m}^{2}$. This area had fire four years ago and the average fire frequency is two to four years.

\subsection{Diheteropogon amplectens-Brachiaria serrata Grassland}

This sub-community occurs along the lower and flatter grassland areas of the reserve, between $1140-1220 \mathrm{~m}$ asl. Rock cover varies between $5-70 \%$ with shallow soil present.

The woody layer has a 1-25\% cover and comprises a few Rhus pyroides shrubs and the dwarf shrubs Fadogia tetraquetra and Pearsonia sessilifolia (species group N). The grass layer covers between $15-70 \%$ of the area while the forb layer has a 15-65\% cover. The dwarf shrub Fadogia tetraquetra (species group $\mathrm{N}$ ) and the grasses Loudetia simplex and Sporobolus pectinatus (species group $\mathrm{M}$ ) totally dominate the vegetation in 
this area. Prominent species include the dwarf shrubs Helichrysum kraussii (species group M), Aeschynomene rehmannii (species group $\mathrm{N}$ ), the grasses Diheteropogon amplectens (species group A), Brachiaria serrata (species group G), the forbs Senecio glaberrimus, Rhynchosia monophylla, Pachystigma latifolium (species group N) and the geophyte Hypoxis rigidula (species group N). The moss fern Selaginella dregei (species group $\mathrm{O}$ ), the forb Kyllinga alba and the geophyte Hypoxis iridifolia (species group $\mathrm{G}$ ) are locally prominent.

With a total size of 43 ha $(8.1 \%$ of the total study area) this sub-community has the highest average number of species/200 $\mathrm{m}^{2}$, namely 38. This area is burned every three to four years.

\subsubsection{Eragrostis gummiflua-Loudetia simplex Grassland}

This variant occurs along the western section of the study area on lower grassland sections (Fig. 4). The altitude varies between 1140-1180 m asl., with a predominantly western slope between $2-8^{\circ}$. The soil is very shallow with a 5-70 \% rocky cover.

The tree layer is absent and only shrubs with an estimated 5-10\% cover are present. The grass layer is dominant and covers between $40-60 \%$ of the area while the forbs have an estimated cover of 15-40\%.

Diagnostic species of this sub-community include the shrub Diospyros lycioides, the grasses Eragrostis gummiflua, Eragrostis racemosa, Digitaria monodactyla, Melinis nerviglumis and the forbs Wahlenbergia undulata, Commelina benghalensis, Trachyandra saltii, Ipomoea bathycolpos, Gladiolus crassifolius and Pearsonia sessilifolia subsp. filifolia (species group $\mathrm{H}$ ).

Dominant species of this sub community are the grasses Sporobolus pectinatus and Loudetia simplex (species group M). Prominent species of this sub community include the dwarf shrub Fadogia tetraquetra (species group $\mathrm{N}$ ), the grass Brachiaria serrata (species group $\mathrm{G}$ ) and the forb $\mathrm{Bul}$ - bostylis burchellii (species group B). The dwarf shrub Parinari capensis (species group N) and the grasses Heteropogon contortus (species group A), Aristida junciformis (species group B), Cymbopogon validus (species group $\mathrm{Q}$ ) and the forbs Pearsonia sessilifolia and Cheilanthes eckloniana (species group N) are also present in this variant.

\subsubsection{Fadogia tetraquetra-Euclea linearis Shrubland}

The Fadogia tetraquetra-Euclea linearis Shrubland occurs scattered throughout the study area on the lower flatter grassland areas (Fig. 4). Altitude ranges between 1140-1220 m above sea level, with a predominantly southern slope of $1-6^{\circ}$. The shallow soil has a 35-70\% rock cover.

Tree and shrub cover varies between 1-20 \%, grass cover between $15-60 \%$ and the forb cover between 10-40\%.

The dwarf shrub Myrothamnus flabellifolia, the grasses Brachiaria serrata, Elionurus muticus, Microchloa caffra, and the forbs Gnidia splendens and Zornia linearis (species group I) are diagnostic for this variant.

The dwarf shrubs Euclea linearis (species group P) and Fadogia tetraquetra (species group $\mathrm{N}$ ) dominate the vegetation, while the dwarf shrubs Pearsonia sessilifolia subsp. sessilifolia (species group $\mathrm{N}$ ) and the grasses Loudetia simplex and Sporobolus pectinatus (species group $\mathrm{M}$ ) are very prominent as well. Other conspicuous species include the tree specie Faurea saligna (species group P) and the forb Aeschynomene rehmannii (species group N). Also present in this variant are, dwarf shrub Indigofera melanadenia (species group P), the grass species Setaria pumila (species group O), Diheteropogon amplectens (species group B) and the forbs Lopholaena coriifolia (species group P) and Rhynchosia monophylla (species group $\mathrm{O}$ ). 
2.4 Senecio glaberrimus-Pearsonia sessilifolia Shrubland

This sub-community occurs in the lower grassland areas along the southern section of the study area (Fig. 4). The altitude is 1140-1180 m asl, with a $2-8^{\circ}$ north-western slope. The soil is very shallow with a 10-80 \% rock cover.

The tree and shrub cover varies between 1-10\% and 5-10\%, respectively, while the grass and forb cover varies between $15-60 \%$ and $10-35 \%$, respectively.

Species from species group $\mathrm{J}$ are diagnostic for this sub-community and include the tree Ximenia caffra, the dwarf shrub Elephantorrhiza elephantina and the forbs Aloe dewetii and Crassula capitella.

The vegetation of this sub-community is dominated by the forbs Senecio glaberrimus (species group $\mathrm{O}$ ) and Pearsonia sessilifolia subsp. sessilifolia (species group N). Prominent species include the tree Englerophytum magalismontanum (species group $\mathrm{P}$ ), the grass specie Hyperthelia dissoluta (species group A) and the forbs Phymaspermum acerosum (species group B) and Cheilanthes eckloniana (species group N). Other species also present in this sub-community include: the tree Vangueria infausta (species group $\mathrm{P})$; the grass Danthoniopsis pruinosa (species group L); and the forbs Aeschynomene rehmannii (species group N), Rhynchosia monophylla (species group O), Rhynchosia nitens (species group Q), Lopholaena coriifolia, and Cryptolepis oblongifolia (species group $\mathrm{P}$ ).

This sub-community comprises approximately 15 ha ( $2.9 \%$ of the total study area) and is exposed to fire every two to three years. An average of 34 species/200 $\mathrm{m}^{2}$ has been recorded within this sub-community.

3. Englerophytum magalismontanum-Helichrysum kraussii Shrubland

Situated in the northern and central sections of the study area (Fig. 4), this community occurs on dry, steep and high-lying areas with altitudes ranging between 1140-1260 m above sea level. The steep slopes vary between $3-19^{\circ}$, while $25-70 \%$ of the shallow soil is covered with rocks.

The woody layer is most prominent with the trees and shrubs covering between 1-15\% and $2-20 \%$, respectively. The grass layer is not well-developed and has a cover of only $20 \%$ while the forb layer covers up to $60 \%$ of the area in some places.

The diagnostic species for this community are: Tetraselago wilmsii, Pellaea calomelanos, Helichrysum uninervium, Smilax anceps, Pteridium aquilinum, and Kotschya parvifolia (species group K).

The woody layer is dominated by the tree Englerophytum magalismontanum (species group $\mathrm{P}$ ), while the grass and forb layers are dominated by Loudetia simplex and Helichrysum kraussii (species group M) respectively. Prominent species in this community include the shrub Rhus pyroides (species group N) and the dwarf shrub Fadogia tetraquetra (species group $\mathrm{N}$ ). Other species conspicuous locally are the trees Syzygium cordatum (species group L) and Faurea saligna (species group P) and the dwarf shrub Euclea linearis (species group P). The grass Cymbopogon vallidus (species group Q) and the forbs Indigofera melanadenia (species group P), Senecio glaberrimus, Hypoxis rigidula (species group $\mathrm{O}$ ) are also present. The endemic small shrub Euclea dewinteri (species group Q) has also been recorded at one locality within this community.

This is one of the larger communities in the study area and comprises close to 65 ha that is $12.4 \%$ of the total study area. An average of 33 species/200 $\mathrm{m}^{2}$ was recorded for this community.

Matthews et al. (1991) described a similar community on the rocky outcrops of the northeastern sourveld. The species composition of this community and the one described by Matthews et al. (1991) shows affinity to the Bankenveld vegetation (Bredenkamp \& Theron 1978; Bredenkamp \& Brown 2003). 
4. Pterocarpus angolensis-Englerophytum magalismontanum Woodland

This community occurs on the highest-lying areas of the study area (Fig. 4). Altitude varies $1140-1300 \mathrm{~m}$ asl, with gentle southwestern slopes ranging between $0-18^{\circ}$. The soil is very shallow with a rockiness of 30-80 \%.

The tree layer has a 5-65\% and the shrub layer $5-50 \%$ coverage compared to the $5-50 \%$ and $5-40 \%$ coverage of the grass and forb layers respectively.

Diagnostic species of this community include: the trees Syzygium legatii, Pterocarpus angolensis, Syzygium cordatum, Ekebergia pterophylla, Brachylaena transvaalensis, Combretum molle, Pterocelastrus echinatus, Parinari curatellifolia, Strychnos spinosa, Cussonia natalensis and Heteropyxis natalensis; the shrubs Ochna confusa and Pavetta schumanniana; the grass Danthoniopsis pruinosa; and the forbs Cyperus esculentus, Anisopappus smutsii, Asparagus virgatus, Aeollanthus parvifolius, Rhoicissus tridentata, Tetradenia riparia and Helichrysum odoratissimum (species group L).

The vegetation is dominated by the trees Pterocarpus angolensis (species group L), Englerophytum magalismontanum and the shrub Euclea linearis (species group P). The grasses Loudetia simplex (species group $\mathrm{M}$ ) and Tristachya leucothrix (species group P) and the forbs Helichrysum kraussii (species group M), Fadogia tetraquetra (species group $\mathrm{N}$ ) and Cryptolepis oblongifolia (species group P) are also prominent. Other conspicuous species include the trees Vangueria infausta, Faurea saligna (species group P) and the shrub like Rhus pyroides (species group N). The grass Sporobolus pectinatus (species group $\mathrm{M}$ ) and the forbs Smilax anceps (species group K), Crotalaria doidgeae (species group M), Aeschynomene rehmania subsp. leptobotra, Cheilanthes eckloniana (species group $\mathrm{N}$ ), Indigofera melanadenia (species group P) are also present within this community.
As the largest community within the study area (137 ha), this community comprises $26 \%$ of the total study area and has the second highest average number of species, i.e., $36 / 200 \mathrm{~m}^{2}$. Due to the shallow soils and species composition this community has a low production, resulting in a susceptibility to fire every four to five years.

\section{Faurea saligna-Cymbopogon vallidus Woodland}

Situated in the northern and central sections of the study area (Fig. 4), this open woodland occurs on steep, high-lying areas with lower altitudes varying between 1160-1200 m above sea level. The moderate to steep south-eastern slopes vary between 5-29 . The shallow soil has a low rock cover ranging between $10 \%$ and $40 \%$.

The tree layer is the most prominent and has an estimated $60 \%$ cover while the shrub layer has a $20 \%$ coverage. The herbaceous layer has a $10-40 \%$ grass cover and a 10-20\% forb cover.

Diagnostic species of this community include the trees Tricalysia lanceolata, Rhus dentata, Rhus transvaalensis, the endemic dwarf shrub Euclea dewinteri, the grass Cymbopogon validus and the forbs Rhynchosia nitens and Polygala hottentotta (species group Q).

The tree Faurea saligna (species group P) and the grass Cymbopogon validus (species group Q) dominate the vegetation. Prominent species include the dwarf shrubs Fadogia tetraquetra and Pearsonia sessilifolia subsp. sessilifolia (species group $\mathrm{N}$ ) and the forb Tetraselago wilmsii (species group $\mathrm{K}$ ).

This community comprises 19 ha which is $3.6 \%$ of the total study area. An average of 28 species/200 $\mathrm{m}^{2}$ was recorded and has not been exposed to fire for the past 14 years.

\section{Combretum kraussii-Acacia ataxacantha Woodland}

This dense indigenous riverine forest occurs along the lower-lying more moist areas on steep slopes and valley bottoms of the Blyde 
River Canyon (Fig. 4). The vegetation is protected against fire and wind resulting in a well-developed woody layer. The altitude varies between 1060-1100 m asl, with moderate to steep east and west-facing slopes ranging between $8-30^{\circ}$. The soil varies between shallow and dry with a high rock cover, to deep and moist soil with a low rock cover.

The vegetation is dominated by the woody layer with $70-100 \%$ coverage, while the herbaceous layer is generally not well developed and has a low cover estimated at 5-40\%.

This community is characterised by the presence of the following diagnostic species: Acacia ataxacantha, Diospyros whyteana, Combretum kraussii, Rhamnus prinoides, Maytenus undata, Maytenus mossambicensis, Ficus ingens, Tarchonanthus camphoratus, Ziziphus mucronata, Dalbergia armata, Erythroxylum delagoense, Bowkeria cymosa, Ochna holstii and Euclea crispa (species group R).

The vegetation is dominated by the trees Acacia ataxacantha and Combretum kraussii (species group R) while the tree Englerophytum magalismontanum (species group $\mathrm{P}$ ) is also prominent.

The presence of the woody species Rhamnus prinoides, Ziziphus mucronata, Grewia occidentalis and Clematis brachiata indicates an affinity with bushveld vegetation Matthews (1991). This community also shows an affinity with the Acacio ataxacanthae-Celticum africanae, an association described by Matthews (1991) which is characteristic for valley bottoms as well as protected areas on valley sides.

\subsection{Englerophytum magalismontanum-Acacia ataxacantha Woodland}

This sub-community occurs along the steep $\left(26^{\circ}-30^{\circ}\right)$ western slopes on the edge of the Blyde River Canyon (Fig. 4). Altitude varies between $1100-1160 \mathrm{~m}$ asl and the shallow soils are mostly covered with large boulders covering approximately $80 \%$ of the area.
The vegetation consists mainly of trees taller than two metres, covering $70-100 \%$ of the area. The shrub layer has a 10-20\% cover while the grass layer is not well developed and covers only $5 \%$. Diagnostic species of this sub-community are the trees Canthium mundianum, Peltophorum africanum and Olinia emarginata (species group S).

The woody layer is dominated by the trees Englerophytum magalismontanum (species group P) and Acacia ataxacantha (species group R). Prominent species includes the trees Ziziphus mucronata, Ficus ingens, Combretum kraussii (species group R) and Heteropyxis natalensis (species group L).

Sections of this small community (9 ha) were disturbed by mining activities 35 years ago. A total of 23 species $/ 200 \mathrm{~m}^{2}$ were recorded for this community, which is burned only every 7-10 years.

\subsection{Combretum kraussii-Acacia ataxacantha Woodland}

This sub community occurs along the lowlying and more protected areas of the study area within indigenous riverine forests (Fig. 4). The altitude varies between 1060$1120 \mathrm{~m}$ above sea level, while the eastfacing slopes are less steep $\left(8-11^{\circ}\right)$ than those of the previous community. The soil is deep and moist and is mostly covered (70 \%) with huge boulders.

The woody vegetation is the most prominent and the trees have about $90 \%$ coverage. The shrub layer covers between $1-20 \%$ of the area while the herbaceous layer is not well developed with only $5 \%$ coverage.

Species belonging to species group $\mathrm{T}$ are diagnostic for this sub-community and include: Clematis brachiata, Clutia pulchella, Cnestis polyphylla, Ficus thonningii, Halleria lucida, Pittosporum viridiflorum, Rawsonia lucida, Mimusops obovata, Canthium inerme, Rothmannia globosa, Sclerochiton harveyanus, Trema orientalis and Grewia occidentalis. 
The woody vegetation is dominated by the trees Combretum kraussii, Acacia ataxacantha and Ziziphus mucronata (species group R), while the trees Rhamnus prinoides (species group R), Rhus dentata (species group Q), Canthium inerme and Halleria lucida (species group T) are also prominent locally.

This community is 55 ha in size ( $11 \%$ of the total study area) and is only burnt every 5-7 years. An average of 31 species $/ 200 \mathrm{~m}^{2}$ was recorded within this sub-community.

\section{Pinus patula Woodland}

This community is situated within a commercial pine plantation outside the Bourke's Luck section of the BCNR and was included in this study to ascertain the differences between the vegetation in the plantations and the adjacent natural vegetation with similar topography and geology. The terrain can be described as flat higher-lying grassland with no rock cover, shallow soil and a gentle slope of $1-2^{\circ}$ southward. The altitude varies from $1260 \mathrm{~m}$ to $1280 \mathrm{~m}$ above sea level. This community comprises a 15-year-old plantation as well as a five-year-old plantation.

The commercially planted tree Pinus patula (species group $U$ ) that is also characteristic for this community dominates the vegetation.

In this 15-year-old plantation, the tree layer has a $90 \%$ cover while the herbaceous layer is extremely degraded and consists of only a few individual grasses and forbs with an estimated $1 \%$ cover. In the five-year-old plantation, the trees cover approximately $40 \%$ of the area while the herbaceous layer is not as degraded as the above and covers approximately $50 \%$ of the area. Other species present include the forb Pentanisia angustifolia and the grass Sporobolus pectinatus (species group $\mathrm{M}$ ). The latter is locally prominent in the younger plantation.

This community is similar in topography to the Diheteropogon amplectens-Pearsonia sessilifolia Shrubland (community 2.1.2), but due to the utilisation of the area for com- mercial forestry has totally different soil and herbaceous characteristics.

\section{Discussion}

As a centre of endemism, the BCNR is a significant conservation area not only for the Mpumalanga Province but also for the larger region. To develop suitable management plans and to determine habitat suitability for different animal species, it is important that more detailed vegetation studies be undertaken to compile an inventory of the flora of a conservation area (Brown et al. 1996).

Although a broad vegetation map exists for the BCNR, no detailed vegetation study has been conducted within the reserve. Previous vegetation studies were conducted on broader plant communities in the region (Deall 1985; Deall et al. 1989b; Matthews 1991). By using Braun-Blanquet procedures a total of 13 different and clearly distinguishable plant communities were identified, described and mapped within the Bourke's Luck section of the Reserve.

One of these communities shows affinity to bushveld communities described by Matthews et al. (1991). Two communities showed affinity to Bankenveld vegetation as described by Bredenkamp \& Theron (1978), Bredenkamp \& Brown (2003). One of the communities shows an association with the Drakensberg vegetation as described by Matthews et al. (1994). The endemic species Euclea dewinteri was also found to be prominent within the Faurea saligna-Cymbopogon validus Woodland (community 5) which implies that special management consideration should be given to this woodland.

The study revealed a total of 263 plant species, representing 73 families and 176 genera. Four families dominate the BCNR flora. The two largest families are, by far, the Asteraceae with 42 species, reflecting $16 \%$ of the total flora and the Poaceae with 35 species (13\%). These are followed by much smaller, yet significant families, represented by the Fabaceae with 22 species (8 \%) and Rubiaceae with 18 species representing 
$7 \%$ of the total flora of the study area. These four families represent $44 \%$ of the BCNR flora, while the other 69 families reflect the remaining $66 \%$.

Fire frequency seems to have an influence on species richness and it would be important that research is undertaken to determine the correct frequency for the various communities within the study area. The average number of species per community per $200 \mathrm{~m}^{2}$ is 30. The Hyperthelia dissoluta-Heteropogon contortus community (community 1) which is burnt nearly every year has the lowest species richness of only 13 species $/ 200 \mathrm{~m}^{2}$. The Diheteropogon amplectens-Brachiaria serrata Grassland (sub-community 2.3), burnt on a three-year cycle, has the highest species richness of all the different plant communities, viz., 38 species $/ 200 \mathrm{~m}^{2}$. The grassland communities with an above-average species richness $(2.1 ; 2.4 ; 3)$ all have fire frequencies ranging between three to four years. Compare this to community 1 that is burnt every year. The woodland communities with below-average species richness (5 \& 6.1) have fire frequencies ranging from 7-14 years, contrasted by community 4 and sub-community 6.1 where fire frequencies range from four to seven years. It therefore seems as though the grassland areas should be burnt on a three to four year cycle while the woodland communities should be burnt every 5-7 years to ensure high species richness.

The data on the habitat use of the baboons (Marais 2005) indicates that the baboons have distinct preferences for certain plant communities and avoided others. The baboons showed a specific preference for the Englerophytum magalismontanum-Acacia ataxacantha Woodland (sub-community 6.1), which is one of the smallest plant communities present at Bourke's Luck, covering an area of only 9.3 ha while they also showed a high preference for Combretum kraussii-Acacia ataxacantha Woodland (sub-community 6.2), which covers a relatively large area (55 ha). These findings suggest that the baboons are most attracted to areas of Acacia woodland. The next most preferred habitats consisted of grassland and shrubland (sub-communities 2.3 and 2.4). The least preferred communities were the Hyperthelia dissoluta-Heteropogon contortus community (community 1) and particularly, the Helichrysum wilmsii-Panicum natalense community (sub-community 2.2).

Baboons are eclectic but highly specialised feeders (Whiten et al. 1987). They consume a wide variety of plant species but may only eat a single part, ingesting only the flowers, seeds or leaves of each one (Barrett 2000). Baboons supplement their diet with animal protein obtained from insects, reptiles, and occasionally, small birds and mammals. In general, they show a preference for fruit over other kinds of foods (Dunbar 1988). The specifics of baboon diet and choice in any one area are determined by local habitat structure and the array of available food species it contains (Henzi et al. 1997). The avoidance of community 1 and sub-community 2.2 can thus be explained by the presence of very few woody species providing food (fruit) to the baboons, while the dominant species in these communities namely the grasses Heteropogon contortus, Hyperthelia dissoluta, Hyparrhenia filipendula, Diheteropogon amplectens (community 1), and Panicum natalense and Loudetia simplex (sub-community 2.2) are all unpalatable grasses providing only limited food to these animals. Marais (2005) has found that the baboons utilise the grass Panicum natalense that is present in sub-community 2, but only in the communities where other food is also available. In the dry winter months, the baboons also showed a shift to underground material of which very little is available in these less-preferred communities (Marais 2005). All of the preferred communities provide an array of different food items explaining the baboons' preference for these communities.

If the baboon population of the study area is to be managed it is important that the current management strategies applied to the broad vegetation units are adapted to separately consider each of the plant communities identified in this study. This is of special interest 
regarding the preferred woodland areas (subcommunities 6.1 and 6.2) and the two grassland/shrubland areas (sub-communities 2.3 and 2.4). The burning of these entire areas will diminish the food available to the baboons. This could result in them leaving the reserve boundaries to find food in adjacent forestry areas. It is therefore important that only smaller sections of these areas are burned within each burning cycle. This will ensure that enough food is available for the baboons in the reserve, while at the same time the growth of grasses is stimulated and moribund material removed in a sustainable manner. It is also recommended that permanent monitoring points are placed in these preferred communities and annual monitoring on the food availability is undertaken to determine the success of the different management strategies applied.

\section{Conclusion}

This inventory of the ecosystems and biota should form the basis for the compilation of a management plan pertaining to vegetation, interpretation and ecotourism for this section of the reserve. The results of this study will enable management of the BCNR to take informed decisions regarding the management of each of these areas.

There is a clear distinction among the 13 plant communities identified and it is recommended that they are managed as separate ecological units. The classification resulted in vegetation units that can be related to environmental factors. No similar detailed vegetation descriptions have previously been completed on the vegetation of the study area and this research therefore provides valuable data on the ecosystems present. An understanding of the plant communities and their associated habitats are of fundamental importance for compiling sound management and conservation strategies. These vegetation surveys and descriptions provide baseline information that allows monitoring as well as similar surveys to be conducted in future. This classification of the plant communities, contributes to the present know- ledge of the reserve and adjacent similar areas. The vegetation map and the description of the various communities can be used to improve the vegetation management plan for this section of the reserve.

This study also forms part of a larger study on the habitat use and range of a single baboon troop. Currently, no formal management plans exist for baboons in most nature reserves. This can be attributed to the limited knowledge of these animals and their effect on and use of different ecosystems. The plant communities identified and described in this study are all situated within the home range of this baboon troop and therefore provides detailed data on the different plant species as well as habitats that exist within their home range. This is essential when determining the amount of time the troop spends in each community / ecosystem within their home range. The data collected in this study will be also be used to develop guidelines for the management of baboon troops in conservation areas. When the dietary requirements of these animals and the plant communities within which these food sources occur are known, it would further aid management when making decisions on the implementation of such a management programme.

The Braun-Blanquet approach again proved to be an accurate and effective way whereby floristically defined plant communities could be classified and identified in the field. This information is essential for management to make scientifically justifiable decisions on which management strategies to implement to ensure biodiversity in terms of plant and animal species.

\section{References}

AnON. 1985. Bontebokhoek - A series of articles on nature conservation. Cape Town: Cape Department of Nature and Environmental Conservation.

BARretT, L. 2000. Baboons; survivors of the African continent. London: Toucan books.

Bezuidenhout, H. 1993. Syntaxonomy and synecology of western Transvaal grasslands, South 
Africa. Ph.D. Thesis. University of Pretoria, Pretoria.

BEzUIDENHOUT, H. 1996. The major vegetation communities of the Augrabies Falls National Park, Northern Cape. 1. The southern section. Koedoe 39: 7-24.

Bezuidenhout, H., Biggs, H.C. \& G.J. BredenKamp. 1996. A process supported by the utility BBPC for analysing Braun-Blanquet data on a personal computer. Koedoe 39: 107-112.

Bigalke, R.C. \& H.J. VAN HensBergen. 1990. Baboon damage in plantation forestry in South Africa. South African Forestry Journal 152: 26-33.

BredenKamp, G.J. 1982. 'n Plantekologiese studie van die Manyeleti-wildtuin. D.Sc. Thesis. University of Pretoria, Pretoria.

BredenKamp, G.J. \& H. Bezuidenhout. 1995. A proposed procedure for the analysis of large data sets in the classification of South African grasslands. Koedoe 38(1): 33-39.

BredenKamp, G.J. \& L.R. Brown. 2001. A reliable ecological basis for environmental planning. Urban Green File November/December 2001: 38-39.

Bredenkamp, G.J. \& L.R. Brown. 2003. A reappraisal of Acocks' Bankenveld: origin and diversity of vegetation types. South African Journal of Botany 69(1): 7-26.

Bredenkamp, G.J., Granger, E. \& N. van RoOyen. 1996. North-eastern mountain grassland. Pp. 4647. In: Low A.B. \& A.G. ReBELo (eds.). Vegetation of South Africa, Lesotho and Swaziland. Pretoria: Department of Environmental Affairs and Tourism.

BredenKamp, G.J. \& G.K. Theron. 1978. A synecological account of the Suikerbosrand Nature Reserve. 1: The phytosociology of the Witwatersrand geological system. Bothalia 12: 523-529.

BROWN, L.R. 2003. The importance of plant ecology to humankind. Unpublished report, Technikon SA.

BRown, L.R. 1997. A plant ecological and wildlife management plan of the Borakalalo Nature Reserve, North-west Province. Ph.D. Thesis. University of Pretoria, Pretoria.

Brown, L.R. \& M.E. BRAND. 2004. Research in nature conservation and tertiary education. Unpublished report, UNISA.

Brown, L.R., BredenKamp, G.J. \& N. van RoOyen. 1996. The phytosociology of the northern section of the Borakalalo Nature Reserve. Koedoe 39: 9-24.

Brown, L.R., BredenKamp, G.J. \& N. VAN RoOyen. 1997. The phytosociological synthesis of the vegetation of the Borakalalo Nature Reserve, North-West Province. South African Journal of Botany 63(5): 242-253.
Cilliers, S.S. 1998. Phytosociological studies of Urban Open Spaces in Potchefstroom, North West Province, South Africa. Ph.D thesis, Potchefstroom University for CHE.

Coetzee, B.J. 1983. Phytosociology, vegetation structure and landscapes of the Central District, Kruger National Park. Dissertationes Botanicae 69: 1-456.

DeAlL, G.B., 1985. A plant-ecological study of the Eastern Transvaal escarpment in the Sabie area. M.Sc. dissertation, University of Pretoria, Pretoria.

DeAll, G.B., Scheepers, J.C. \& C.J. Schutz. 1989a. The vegetation ecology of the eastern Transvaal escarpment in the Sabie area. 1. Physical environment. Bothalia 19:53-67.

Deall, G.B., Theron, G.K. \& R.H. Westvaal. $1989 \mathrm{~b}$ The vegetation ecology of the Eastern Transvaal Escarpment in the Sabie area 2. Floristic classification. Bothalia 19: 69-89.

De Vore, I. \& K.R.L. Hall. 1965. Baboon ecology. Pp. 20-52. In: De Vore, I. (ed). Primate behaviour: field studies of monkeys and apes. New York: Holt, Rhinehart \& Winston.

Dunbar, R.I.M. 1988. Primate social systems. London: Chapman and Hall.

Fourie, S., Jacobsen, N.H.G., Kleynhans, C.J. \& W. TARBoton. 1988. Bio-geographical importance of species/areas warranting particular conservation attention. Pp. 46-69. In: FERrAR, A.A., ISAACS, G. \& J.R. STACEY (ed.). Environmental conservation features of the Transvaal Escarpment. Pretoria: CSIR. (Occasional Report 31.)

FULLS, E.R. 1993. Vegetation ecology of the northern Orange Free State. Ph.D thesis. University of Pretoria, Pretoria.

Fulls, E.R., BREDEnKamp, G.J. \& N. van RoOyen. 1992. The plant communities of the undulating grassland of the Vredefort - Kroonstad - Lindley - Heilbron area, northern Orange Free State. South African Journal of Botany 58: 224-230.

Germishuizen, G. \& N.L. Meyer. 2003. Plants of southern Africa: an annotated checklist. Pretoria: National Botanical Institute. (Strelitzia 14.)

Greyling, T. \& B.J. Huntley. 1984. Directory of southern African conservation areas. Pretoria: Council for Scientific and Industrial Research, National Scientific Programmes Unit. (South African National Scientific Programmes report; no. 98.)

HenneKens, S.M. 1996a. Megatab: A visual editor for phytosociological tables users guide Version October 1996, IBN-DLO. Lancaster: Wageningen and Lancaster University.

Hennekens, S.M. 1996b. TuRBOVEG: A software package for input, processing and presentation of phytosociological data. User's guide, version July 1996, IBN-DLO. Lancaster: Wageningen and Lancaster University. 
HenZI, S.P., J.E. Lycett, T. Weingrill, R. Byrne \& A. Whiten. 1997. The effect of troop size on travel and foraging in mountain baboons. South African Journal of Science 93: 333 - 335.

HILl, M.O. 1979. TWINSPAN: A FORTRAN program for arranging multivariate data in an ordered twoway table classification of individuals and attributes. New York: Cornell University.

LAND Type Survey StafF. 1989. Land types of the maps 2330 Tzaneen and Pilgrim' Rest. Memoirs on the Agricultural Natural Resources of Southern Africa 12: 1-415.

LotTer, M., Burrows, J. \& A.J. Emery. 2002. Phytochoria: Centres and regions of endemism. In: LotTer, M., A.J. EMER, \& S.D. Williamson (eds.). Determining the conservation value of land in Mpumalanga. Internal report, Mpumalanga Parks Board, Lydenburg.

MARAIS, A.J. 2005. Resource utilisation of the chacma baboon in different vegetation types in northeastern mountain sour veld, Blyde Canyon Nature Reserve. M.Tech. dissertation. University of South Africa, Florida.

Matthews, W.S.1991. Phytosociology of the Northeastern Mountain sourveld. M.Sc dissertation. University of Pretoria. Pretoria.

Matthews, W.S., G.J. BRedenKamp \& N. VAN RoOYEN. 1991. The vegetation of the Black Reef Quartzite and the associated large rocky outcrops in the north-eastern mountain sourveld of the Transvaal escarpment. South African Journal of Botany 57(3): 143-150.

Matthews, W.S., G.J. BredenKamp \& N. VAN RoOYEN. 1994. The phytosociology and syntax- onomy of relative low-altitude areas in the North-eastern Mountain Sourveld, in the eastern Transvaal escarpment region. Koedoe 37(2): 73-87.

MatThews, W.S., A.E. VAN WYK \& G.J. BREDENKAMP. 1993. Endemic flora of the Northeastern Transvaal Escarpment, South Africa. Biological Conservation 63: 83-94.

MuCinA, L. \& E. VAN DER MAAREL. 1989. Twenty years of numerical syntaxonomy. Vegetatio 81 : $1-15$.

Mueller-Dombois, D. \& H. Ellenburg. 1974. Aims and methods of vegetation ecology. New York: Wiley.

TUELlER, P.T. 1988. Vegetation science applications for rangeland analysis and management. Dordrecht: Kluwer Academic Publishers.

Van Rooyen, N., Theron G.K. \& N. GrobbelaAr. 1981. A floristic description and structural analysis of the communities of Punda MiliaPafuri-Wambiya area in the Kruger National Park, Republic of South Africa. 1. The hygrophilous communities. South African Journal of Botany 47:213-246.

Westhoff, V. \& E. VAN Der MaArel. 1978. The Braun-Blanquet approach. Pp. 287-399. In: WhitTAKer, R.H. (ed). Classification of plant communities. The Hague: Junk.

Whiten, A., R.W.,Byrne \& S.P. Henzi. 1987. The behavioral ecology of mountain baboons. International Journal of Primatology 8:367-388.

Whittaker, R.H. 1978. Dominance types. Pp. 65-79. In: WHITTAKER, R.H. (ed). Classification of plant communities. The Hague: Junk. 